\title{
Management of Sumatran fleabane after maize harvest in the fallow period shorter than 60 days
}

\author{
Antonio Mendes de Oliveira Neto ${ }^{1 *}$, Jamil Constantin ${ }^{2}$, Rubem Silvério de Oliveira Júnior ${ }^{2}$, Naiara Guerra $^{3}$, \\ Eder Blainski ${ }^{4}$ and Hugo de Almeida Dan ${ }^{5}$
}

\author{
${ }^{1}$ State University of Santa Catarina, Lages, SC, Brazil. \\ ${ }^{2}$ State University of Maringá, Maringá, PR, Brazil. \\ ${ }^{3}$ Federal University of Santa Catarina, Curitibanos, SC, Brazil. \\ ${ }^{4}$ Terra Research and Agricultural Training, Assis Chateaubriand, PR, Brazil. \\ ${ }^{5}$ AgroFarm Agronomic Research and Consultancy, Cerejeiras, RO, Brazil. \\ *Author for correspondence: am.oliveiraneto@gmail.com
}

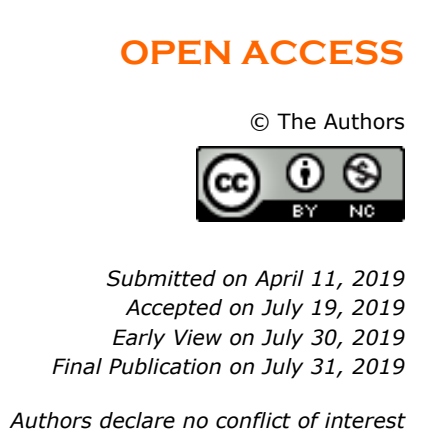

Authors declare no conflict of interest

KEYWORDS: Conyza spp Herbicide resistance Tank mixes EPSPs

\section{ABSTRACT}

Sumatran fleabane is an important weed in Brazilian crop production systems due to glyphosate resistance and broad adaptation to no-till environments, mainly in the crop succession with soybean sowed in first-season (September to February) followed by maize in second-season (February to June). The fallow period between maize harvest and the next soybean sowing allows Sumatran fleabane to emerge and grow. On the other side, fallow is a suitable moment for Sumatran fleabane control because plants are more susceptible to herbicide in initial stages of growth. In this study, the aim was to evaluate the effectiveness on combined burndown + residual herbicide treatments to control Sumatran fleabane during fallow, after maize harvest. Two experiments were carried out in Campina da Lagoa (PR) and Floresta (PR) and treatments consisted of combinations of herbicides to provide control of emerged plants of Sumatran fleabane (glyphosate + 2,4-D, MSMA and glufosinate), applied isolated or in tank mixes with residual herbicides (metsulfuron, chlorimuron, diclosulam, imazethapyr, imazaquin, flumioxazin, metribuzin, amicarbazone and isoxaflutole) which were expected to prevent the emergence and growth of new weed fluxes. At the time of herbicides application, Sumatran fleabane plants were no taller than $12 \mathrm{~cm}$. Assessments on both efficacy and residual control were performed until soybean crop sowing (45 days after treatment). Glyphosate +2,4-D mixture was efficient for burndown of Sumatran fleabane. For fallow periods of 45 days, all glyphosate $+2,4$-D mixtures with residual herbicides were efficient for Sumatran fleabane control, providing less than 10 plants $\mathrm{m}^{-2}$ and a maximum plant height of $16 \mathrm{~cm}$ at soybean sowing date.

\section{Highlighted Conclusion}

Glyphosate + 2,4-D + residual herbicides, MSMA + metsulfuron or chlorimuron, glufosinate + metsulfuron, chlorimuron, diclosulam, metribuzin and amicarbazone are efficient for Sumatran fleabane control since these treatments provided very low infestations and limited growth of newly emerged plants at next sowing date.

\section{INTRODUCTION}

Conyza plants (Conyza bonariensis, $C$. canadensis and $C$. sumatrensis) are spread worldwide infesting more than 40 different crops and non-agricultural lands (Lazaroto et al. 2008). C. canadensis (150 plants per $\mathrm{m}^{-2}$ density) may reduce the soybean productivity under direct sowing system by $83 \%$ (Bruce and Kells 1990). Besides quantitative losses, competition between Sumatran fleabane and soybean depreciates grain quality, by increasing both moisture content and impurities (Constantin et al. 2013). Thus, eroding the value received by the product.

Intense utilization of glyphosate in production systems of fruits and soybean crop, particularly in conservationist management systems such as no-till, favored the selection of $C$. bonariensis e $C$. canadensis resistant biotypes (Vidal et al. 2007). In addition, the commercial introduction of glyphosate-resistant transgenic soybean led to an additional use of two to three applications of this herbicide per crop season, what has favored the selection of resistant populations of Conyza sp. (Vargas et al. 2007). Multiple resistance to glyphosate and Acetolactate 
Synthase (ALS) inhibitors in Sumatran fleabane (C. sumatrensis) was confirmed in 2014 in soybean and maize fields from Paraná State (Santos et al. 2014). In 2017, in the same area (western Paraná), C. sumatrensis biotypes were selected with multiple resistance to glyphosate (EPSPs inhibitor), paraquat (PSI inhibitor), diuron (PSII inhibitor), saflufenacil (PPO inhibitor) and 2,4-D (synthetic auxins) (Heap 2019).

When herbicide-resistant biotypes reach a density high enough to limit crop yield, there is a need for change in current management practices, as well as for developing alternative strategies for controlling resistant populations (López-Ovejero et al. 2006; Lamego and Vidal 2008; Moreira et al. 2010).

One of these alternative strategies used for controlling glyphosate-resistant Sumatran fleabane biotypes is the application of mixtures with post-emergence herbicides with alternative mechanisms of action. Preliminary research has shown that 2,4-D, glufosinate and MSMA are alternative herbicide options (Blainski 2011).

In the western and northern regions of Paraná, the fallow period, which is the interval from second maize harvest to the next spring crop sowing may last from 45 to 90 days. In those areas, the maize harvesting period can be divided into early harvest, when it is performed not later than July 15 (fallow $>60$ days), and late harvest, when it is performed after July 15 (fallow <60 days) (Oliveira Neto et al. 2017). This division is important because each harvest period demands particular fallow management strategies. For the early harvested maize, Sumatran fleabane emergence peak generally occurs after its harvest; whereas for the late harvested maize, it usually occurs before the end of crop cycle.

The aim of this research was to evaluate the efficiency on burndown and residual control of glyphosate+2,4-D, glufosinate and MSMA isolated or mixed with residual herbicides on Sumatran fleabane after the maize harvest during fallow.

\section{MATERIAL AND METHODS}

Two field experiments were performed from June to October 2009. The first one was carried out at Campina da Lagoa, PR $\left(23^{\circ} 33^{\prime} 59,36^{\prime \prime} \mathrm{S}, 5^{\circ} 41^{\prime} 31,24^{\prime \prime} \mathrm{W}\right.$ and altitude of $\left.607 \mathrm{~m}\right)$ and the second one at Floresta, PR $\left(23^{\circ} 36^{\prime} 32,04^{\prime \prime} \mathrm{S}, 52^{\circ} 05^{\prime} 37,64^{\prime \prime} \mathrm{W}\right.$ and altitude of $\left.355 \mathrm{~m}\right)$. Both experiments were carried out in areas with a history of soybean-second maize cropping succession and failures in Sumatran fleabane control after glyphosate application, providing evidences of resistance to EPSPs inhibitor.

Soils from experimental areas were identified as eutrophic Red Oxisoil (Embrapa 2013), clay texture. In Campina da Lagoa, soil presented $600 \mathrm{~g} \mathrm{~kg}^{-1}$ clay and $32.75 \mathrm{~g} \mathrm{dm}^{-3}$ Organic Carbon, while in Floresta, $630 \mathrm{~g} \mathrm{~kg}^{-1}$ clay and $16.81 \mathrm{~g} \mathrm{dm}^{-3}$ Organic Carbon. These soil properties contribute to enhance herbicide sorption and persistence. Regional climate is subtropical with summer rains and dry winters (Cfa, according to Köppen climate classification). The rainfall distribution was suitable to provide favorable conditions to germination, emergence and initial growth of Sumatran fleabane (Figure 1).

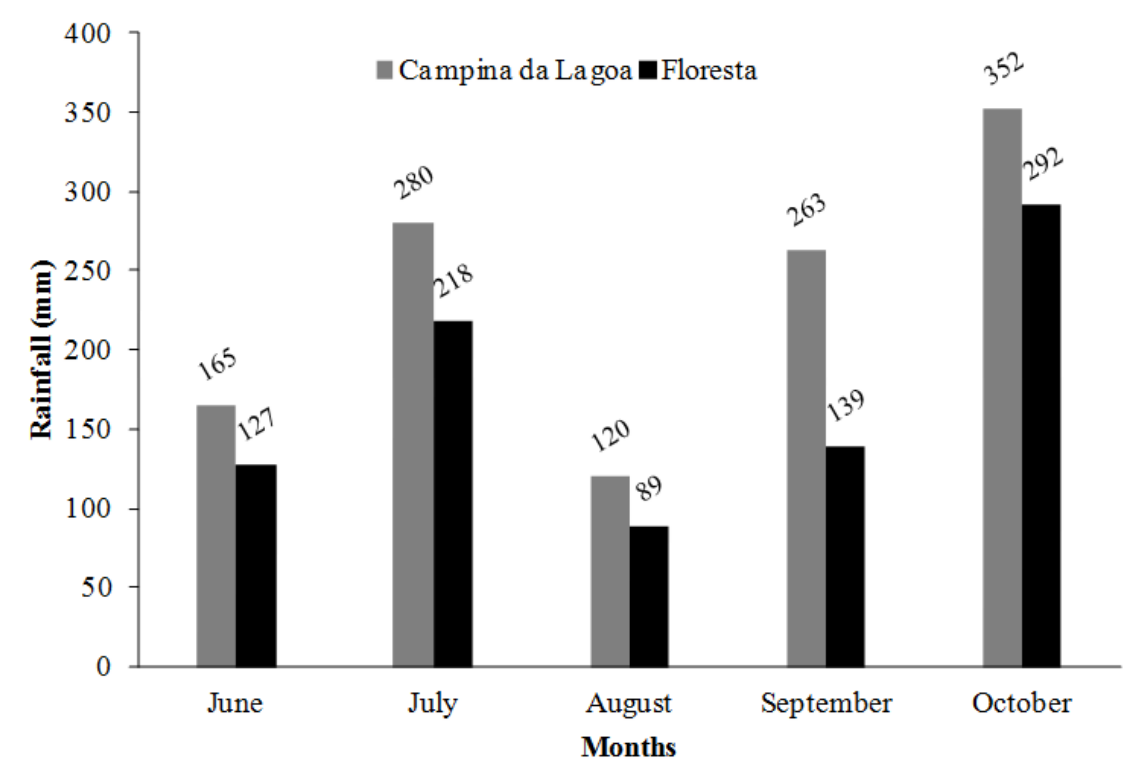

Figure 1. Monthly rainfall during the time of conducting experiments in two locations in Paraná State, Brazil.

At each location, one experiment was carried out after maize harvesting, between the second half of June and early July. In this situation, the fallow period from maize harvesting to the burndown application before soybean 
sowing was 45 days. After maize harvesting, there was a 15 days period before treatment application, due to the need to stabilize crop residues on soil surface, in order to enable both burndown efficacy and uniform distribution of residual herbicides in soil. Treatments were identical for both experiments. We compared three burndown options (glyphosate + 2,4-D $960+536 \mathrm{~g} \mathrm{ha}^{-1}$, MSMA 2,370 $\mathrm{g} \mathrm{ha}^{-1}$ and glufosinate $400 \mathrm{~g} \mathrm{ha}^{-1}$ ) applied isolated or in tank mixes with nine herbicides with residual activity in soil (metsulfuron $3.6 \mathrm{~g} \mathrm{ha}^{-1}$, chlorimuron $20 \mathrm{~g} \mathrm{ha}^{-1}$, diclosulam $33.6 \mathrm{~g} \mathrm{ha}^{-1}$, imazethapyr $100 \mathrm{~g} \mathrm{ha}^{-1}$, imazaquin $180 \mathrm{~g} \mathrm{ha}^{-1}$, flumioxazin $125 \mathrm{~g} \mathrm{ha}^{-1}$, metribuzin $480 \mathrm{~g} \mathrm{ha}^{-1}$, amicarbazone $420 \mathrm{~g} \mathrm{ha}^{-1}$ and isoxaflutole $\left.56.25 \mathrm{~g} \mathrm{ha}^{-1}\right)$. The combination of MSMA + imazaquin was replaced by amicarbazone (560 $\left.\mathrm{g} \mathrm{ha}^{-1}\right)$ due to tank mixture incompatibility. A non-applied check and one burndown treatment with glyphosate isolated at $960 \mathrm{~g} \mathrm{ha}^{-1}$ were also included, totalizing 32 treatments. Both experiments were arranged in a completely randomized block design, with four replicates.

Treatments with glyphosate + 2,4-D, glyphosate, MSMA and glufosinate were used to control emerged Sumatran fleabane plants and residual herbicides were included to prevent new weed fluxes up to the next sowing date. Herbicide applications were done when plants were in early development stage, no taller than $12 \mathrm{~cm}$. That stage was chosen due to the increased susceptibility to herbicide and to the limited sprouting capacity in early stages of Conyza development (Vangessel et al. 2009; Moreira et al. 2010, Oliveira Neto et al. 2010). Herbicide applications were performed with a backpack $\mathrm{CO}_{2}$ sprayer calibrated to deliver $200 \mathrm{~L}^{-1}$ using $207 \mathrm{kPa}$ as $\mathrm{CO}_{2}$ pressure and five XR-110.02 nozzles. Climatic conditions, weed density and height in each location are shown in Table 1.

Table 1. Weather conditions, description of the locations and size of Sumatran fleabane plants at the time of application of treatments in different locations of Paraná State, Brazil.

\begin{tabular}{lcc}
\hline Specifications & Campina da Lagoa & Floresta \\
\hline Sprayed date & $05 / 08 / 2009$ & $13 / 08 / 2009$ \\
Temperature $\left({ }^{\circ} \mathrm{C}\right)$ & 24 & 30 \\
Relative humidity $(\%)$ & 81 & 55 \\
Soil conditions & Moist & Dry \\
Wind $\left(\mathrm{km} \mathrm{h}^{-1}\right)$ & 4.0 & 1.0 \\
Weather & Sunny & Sunny \\
Straw $\left(\mathrm{t} \mathrm{ha}^{-1}\right)$ & 5.58 & 4.63 \\
Soil cover $(\%)$ & 93 & 90 \\
Density $\left(\right.$ plants per $\left.\mathrm{m}^{2}\right)$ & 32 & 356 \\
Plant Height $(\mathrm{cm})$ & $2-12$ & $4-12$ \\
Infestation $(\%)$ & 90 & 95 \\
\hline
\end{tabular}

Visual Sumatran fleabane control ratings were collected at 15 and 30 days after application (DAA). The ratings were based on 0 to $100 \%$ scale, where 0 means no control and 100 correspond to weed completely dead or absence of weeds. Density of emerged Sumatran fleabane plants was determined up to soybean sowing (45 DAA). Sumatran fleabane density was counted using four randomized sampling frames of $0.25 \mathrm{~m}^{2}$ per experimental unit. In these evaluations, the height of Sumatran fleabane was also measured from the root collar to its apical growth region.

Data from each experiment were submitted to F-test variance analysis. As experiments has the same structure and residual average square values showed homogeneous variance, a joint analysis was performed (Banzatto and Kronka 2008) and means compared by Scott-Knott test $(p<0.05)$.

\section{RESULTS AND DISCUSSION}

Tank mixes with residual herbicides improved Sumatran fleabane control to glyphosate $+2,4-\mathrm{D}$, glufosinate and MSMA in Campina da Lagoa (data not showed). Burndown control $>90 \%$ when residual herbicides were mixed with glyphosate + 2,4-D was also observed by Steckel et al. (2006) and by Jaremtchuk et al. (2008). Except for tank mix of glyphosate $+2,4-D+$ imazethapyr did not improve the Sumatran fleabane control in burndown in Campina da Lagoa. These results are similar to related by Procópio et al. (2006), who found that glyphosate + imazethapyr did not improve weed control in burndown.

The experiment carried out in Floresta presented the highest Sumatran fleabane density (356 plants per $\mathrm{m}^{-2}-$ Table 1) at the burndown application. In this location, treatments with glyphosate $+2,4-\mathrm{D}$ or glufosinate controlled efficiently Sumatran fleabane (data not showed). Treatments with MSMA controlled less than $80 \%$ in every tank 
mixing evaluated. These results indicate that MSMA is not an efficient option for Sumatran fleabane control in burndown.

Herbicides sprayed in the fallow period reduced Sumatran fleabane densities in Campina da Lagoa and Floresta up to 45 DAA. The best treatments grouped by Scott-Knott test presented Sumatran fleabane densities $<10$ plants $\mathrm{m}^{-2}$ both in Campina da Lagoa and Floresta (Table 2).

Table 2. Density (plants $\mathrm{m}^{-2}$ ) and plant height $(\mathrm{cm})$ of Sumatran fleabane at 45 DAA in Campina da Lagoa and Floresta, Paraná State, Brazil.

\begin{tabular}{|c|c|c|c|c|c|c|}
\hline \multirow{3}{*}{$\begin{array}{l}\text { Treatments } \\
\text { Glyphosate }\end{array}$} & \multicolumn{3}{|c|}{ Campina da Lagoa } & \multicolumn{3}{|c|}{ Floresta } \\
\hline & \multicolumn{2}{|c|}{ Density $^{*}$} & \multirow{2}{*}{$\begin{array}{c}\text { Height }^{* *} \\
23\end{array}$} & \multicolumn{2}{|c|}{ Density } & \multirow{2}{*}{$\begin{array}{c}\text { Height } \\
8\end{array}$} \\
\hline & 9.0 & $\mathrm{c}$ & & 11.3 & $f$ & \\
\hline Glyphosate + 2,4-D & 4.0 & $c$ & 20 & 7.0 & $g$ & 5 \\
\hline Glyphosate + 2,4-D + metsulfuron-methyl & 2.5 & $c$ & 8 & 5.0 & $g$ & 6 \\
\hline Glyphosate $+2,4-D+$ chlorimuron-ethyl & 0.0 & $c$ & 5 & 1.8 & $g$ & 5 \\
\hline Glyphosate + 2,4-D + diclosulam & 1.0 & $c$ & 6 & 2.3 & $g$ & 2 \\
\hline Glyphosate + 2,4-D + imazethapyr & 4.5 & $c$ & 12 & 9.3 & $f$ & 15 \\
\hline Glyphosate $+2,4-D+$ imazaquin & 3.0 & $c$ & 16 & 1.8 & $g$ & 5 \\
\hline Glyphosate + 2,4-D + flumioxazin & 3.0 & $c$ & 12 & 2.3 & $g$ & 7 \\
\hline Glyphosate $+2,4-D+$ metribuzin & 1.5 & $c$ & 10 & 2.0 & $g$ & 8 \\
\hline Glyphosate + 2,4-D + amicarbazone & 2.0 & $\mathrm{c}$ & 11 & 6.5 & $g$ & 3 \\
\hline Glyphosate $+2,4-D+$ isoxaflutole & 1.3 & $c$ & 9 & 3.3 & $g$ & 6 \\
\hline Glufosinate & 5.0 & $c$ & 30 & 25.0 & $\mathrm{e}$ & 8 \\
\hline Glufosinate + metsulfuron-methyl & 5.8 & $c$ & 16 & 14.3 & $f$ & 7 \\
\hline Glufosinate + chlorimuron-ethyl & 1.3 & $c$ & 12 & 4.5 & $g$ & 7 \\
\hline Glufosinate + diclosulam & 2.0 & $c$ & 11 & 12.3 & $f$ & 7 \\
\hline Glufosinate + imazethapyr & 4.3 & $\mathrm{c}$ & 18 & 22.8 & $\mathrm{e}$ & 9 \\
\hline Glufosinate + imazaquin & 3.0 & $c$ & 17 & 29.3 & e & 10 \\
\hline Glufosinate + flumioxazin & 3.0 & $\mathrm{c}$ & 22 & 13.5 & $f$ & 9 \\
\hline Glufosinate + metribuzin & 2.5 & $c$ & 15 & 3.8 & $g$ & 7 \\
\hline Glufosinate + amicarbazone & 1.5 & $c$ & 11 & 13.8 & $f$ & 7 \\
\hline Glufosinate + isoxaflutole & 3.0 & $c$ & 18 & 5.3 & $g$ & 7 \\
\hline MSMA & 26.8 & $\mathrm{~b}$ & 36 & 78.5 & $c$ & 28 \\
\hline MSMA + metsulfuron-methyl & 5.5 & $c$ & 13 & 47.0 & $d$ & 9 \\
\hline MSMA + chlorimuron-ethyl & 8.3 & $\mathrm{c}$ & 16 & 26.5 & $\mathrm{e}$ & 9 \\
\hline MSMA + diclosulam & 17.5 & $b$ & 18 & 78.3 & $c$ & 25 \\
\hline MSMA + imazethapyr & 24.0 & $\mathrm{~b}$ & 25 & 87.8 & $b$ & 22 \\
\hline MSMA + flumioxazin & 16.8 & $\mathrm{~b}$ & 35 & 74.5 & $c$ & 26 \\
\hline MSMA + metribuzin & 8.0 & $c$ & 20 & 15.3 & $f$ & 19 \\
\hline MSMA + amicarbazone & 4.5 & $c$ & 17 & 59.3 & $d$ & 6 \\
\hline MSMA + isoxaflutole & 7.3 & $c$ & 22 & 54.5 & $d$ & 20 \\
\hline Amicarbazone & 7.3 & $c$ & 25 & 52.5 & $d$ & 27 \\
\hline Untreated & 72.0 & $a$ & 55 & 184.0 & a & 33 \\
\hline CV (\%) & & & & & & \\
\hline
\end{tabular}

Tank mixes with glyphosate $+2,4-\mathrm{D}$ reduced plant densities to fewer than 5 and 10 plants $\mathrm{m}^{-2}$ in Campina da Lagoa and Floresta, respectively, regardless of residual herbicide. Post-emergence Sumatran fleabane control played a fundamental role on the reduction of emerged plants, because the control provided by glyphosate $+2,4-\mathrm{D}$ was enough to group it among the most effective ones. In this research, the short fallow period ( 45 days) may have contributed to the efficient control, by the combination of short 2,4-D residual activity, along with the short Sumatran fleabane emergence period. C. canadensis requirements to high germination include temperatures of $24 / 20{ }^{\circ} \mathrm{C}$ (day/night), light availability, neutral to alkaline soil $\mathrm{pH}$, no water stress and seeds on the soil surface (no deeper 
than $0.5 \mathrm{~cm}$ ) (Nandula et al. 2006). In our experiments, soil moisture and temperature were inadequate to Sumatran fleabane germination and emergence throughout August (Figure 1). For 2,4-D, studies carried out to evaluate its persistence in the environment (Altom and Stritzke 1973; Foster and Mckercher 1973; Plumb et al. 1977; Procópio et al. 2009) found half-lives no longer than seven days (Senseman 2007). 2,4-D is readily degraded and mineralized by a wide range of microorganisms, and $58 \%$ of the initially sprayed $2,4-\mathrm{D}$ was already mineralized after 64 days (Nowak et al. 2011).

Treatments with glufosinate reduced Sumatran fleabane density in Campina da Lagoa from 32 to less than 6 plants $\mathrm{m}^{-2}$ (Table 2). However, in Floresta treatments based on glufosinate presented Sumatran fleabane densities from 3.8 to 29.3 plants $\mathrm{m}^{-2}$, and tank mixing with chlorimuron, metribuzin or isoxaflutole were the most efficient treatments providing Sumatran fleabane densities $<6$ plants $\mathrm{m}^{-2}$ (Tabela 2). There was an increased number of non-controlled plants in Floresta as compared to Campina da Lagoa, due to the higher Sumatran fleabane density at the application time (Table 1). The higher density and soil cover may have prevented spray droplets to deposit on plants occupying an inferior position of the canopy, i.e., "umbrella" effect. Under these conditions, efficacy of contact herbicides like glufosinate could be strongly affected.

MSMA performance was different in the experiments (Table 2). In Campina da Lagoa, tank mixes of MSMA + metsulfuron, MSMA + chlorimuron, MSMA + metribuzin and MSA + amicarbazone were efficient to reduce Sumatran fleabane density $\left(<10\right.$ plants per $\left.\mathrm{m}^{-2}\right)$. However, in Floresta all treatments based on MSMA presented high Sumatran fleabane density, from 15.3 to 87.8 plants per $\mathrm{m}^{2}$.

Although emerged weed density is an important factor in evaluating the treatment efficiency, another relevant factor to consider is the size of emerged plant close to or at sowing date of the next crop. Few chemical management alternatives will provide efficient control of Sumatran fleabane plants with $\geq 16 \mathrm{~cm}$ (Blainski 2011). For this reason, an additional criterion was adopted to rank treatments performance based on the size of remaining plants at the date of soybean sowing. Efficient herbicide treatments should provide remaining plants with a maximum of $16 \mathrm{~cm}$.

In Campina da Lagoa, treatments with glyphosate, glyphosate + 2,4-D, glufosinate, MSMA and amicarbazone did not provided suppression of Sumatran fleabane growth, resulting in plants $>16 \mathrm{~cm}$ (Table 2). Although treatments with glyphosate $+2,4-\mathrm{D}$ were effective on burndown and Sumatran fleabane density reduction, remaining plants were $20 \mathrm{~cm}$ tall at summer crop sowing date (45 DAA). Even though this plant size restricts control options on burndown prior to spring crop sowing, an adequate control might still be achieved, for instance, with tank mixing of glyphosate + 2,4-D at 1080+1005 g ha-1 (Oliveira Neto et al. 2010). However, the 2,4-D application on soybean pre-planting burndown is somewhat limited due to the possibility of causing damage to the crop. In a study carried out by Procópio et al. (2009), utilization of 2,4-D (670 $\left.\mathrm{g} \mathrm{ha}^{-1}\right)$ did not affect soybean yield even when burndown and sowing were both performed in the same day. Nevertheless, an interval of at least seven days between 2,4-D and soybean crop sowing is recommended (Rodrigues and Almeida 2011).

Tank mixing of glyphosate $+2,4-D$ with residual herbicides suppressed Sumatran fleabane growth, so that plants were about the same size or shorter than $16 \mathrm{~cm}$ at 45 DAA. For glufosinate, tank mixing with metsulfuron, chlorimuron, diclosulam, metribuzin or amicarbazone also showed appropriate heights for a 45 days fallow period in Campina da Lagoa (Table 2). In general, treatments with MSMA resulted in plants taller than $16 \mathrm{~cm}$. However, tank mixing of MSMA with metsulfuron or chlorimuron resulted in good growth suppression, with Sumatran fleabane height $<16 \mathrm{~cm}$.

In Floresta, many treatments were efficient to suppress Sumatran fleabane growth (height $\leq 16 \mathrm{~cm}$ ), including low or no residual herbicide treatment like glyphosate, glufosinate and glyphosate $+2,4-\mathrm{D}$ (Table 2). This result demonstrated the possibility to manage Sumatran fleabane during fallow period only with the application of herbicides without residual activity. This possibility may lead to more cost-effective treatments to farmers. However, some treatments (amicarbazone, MSMA isolated or in tank mixing with diclosulam, imazethapyr, flumioxazin, metribuzin or isoxaflutole) (Table 2) were not efficient to suppress Sumatran fleabane growth, and results in plants $>16 \mathrm{~cm}$. Both in Campina da Lagoa and Floresta herbicides metsulfuron and chlorimuron were efficient when combined with any of the three burndown treatments. This was due to the good control and suppression imposed by these herbicides when applied to Sumatran fleabane plants in early stages of development (Vargas et al. 2007). In both experiments, Sumatran fleabane was $\leq 12 \mathrm{~cm}$ at the application time (Table 1).

By analyzing the results of both experiments for Sumatran fleabane density and height, we conclude that only a few treatments provided efficient control of emerged plants combined with effective residual effect to suppress new emergence flux and/or limited new Sumatran fleabane growth. Briefly, only treatments based on glyphosate $+2,4-$ $\mathrm{D}+$ residual herbicides (all evaluated), glufosinate + chlorimuron and glufosinate + metribuzin presented Sumatran fleabane densities $<10$ plants $\mathrm{m}^{-2}$ and plants $\leq 16 \mathrm{~cm}$ at sowing date both in Campina da Lagoa and Floresta. 
Results obtained for this fallow time (45 days) should not be extrapolated for longer fallow periods (>60 days), because in this case a longer period of residual control is required.

The treatments based on glyphosate $+2,4-\mathrm{D}+$ residual herbicides, glufosinate + chlorimuron and glufosinate + metribuzin provided Sumatran fleabane densities of less than 10 plants per $\mathrm{m}^{2}$ and maximum plant height of $16 \mathrm{~cm}$ in Campina da Lagoa and Floresta at soybean sowing date, 45 days after treatments application.

\section{Acknowledgments}

The author expresses his appreciation to Coordenação de Aperfeiçoamento de Pessoal de Nível Superior (CAPES) for the grant awarded.

\section{References}

Altom JD and Stritzke JF. 1973. Degradation of dicamba, picloram and four phenoxy herbicides in soils. Weed Science 6:556-560.

Banzatto DA and Kronka SN. 2008. Experimentação agrícola. FUNEP: Jaboticabal.

Blainski, E. 2011. Herbicidas alternativos para o controle de Conyza spp. em diferentes estádios de desenvolvimento e monitoramento de fluxos de emergência em campo. 2011. Dissertation, University of Maringá, Maringá, Brazil. Available in: http://www.napd.uem.br/up/PublicNAPD_9af04910f75dd6a4c2e88ac32f104b8d9gwRC.pdf

Bruce $J$ and Kells J. 1990. Horseweed (Conyza canadensis) control in no-tillage soybeans (Glycine max) with preplant and preemergence herbicides. Weed Technology 4:642-647.

Constantin J et al. 2013. Buva: fundamentos e recomendações para manejo. Curitiba: Ominipax.

Embrapa - Empresa Brasileira de Pesquisa Agropecuária. 2013. Sistema brasileiro de classificação de solos. 3 ed. Brasília: Embrapa.

Foster RK and McKercher RB. 1973. Laboratory incubation studies of chlorophenoxyacetic acids in chernozemic soils. Soil Biology and Biochemistry 5:333-337.

Heap I. 2019. The international survey of herbicides resistant weeds. Available in: <http://weedscience.com/default.aspx>. Access on: Mar 8 , 2019.

Jaremtchuk CC et al. 2008. Efeito de sistemas de manejo sobre a velocidade de dessecação, infestação inicial de plantas daninhas e desenvolvimento e produtividade da soja. Acta Scientiarum. Agronomy 30:449-455.

Lamego FP and Vidal RA. 2008. Resistência ao glyphosate em biótipos de Conyza bonariensis e Conyza canadensis no estado do Rio Grande do Sul, Brasil. Planta Daninha 26:467-471.

Lazaroto CA et al. 2008. Biologia e ecofisiologia de buva (Conyza bonariensis e Conyza canadensis). Ciência Rural 38:852-860.

López-Ovejero RF et al. 2006. Alternativas de manejo químico da planta daninha Digitaria ciliaris resistente aos herbicidas inibidores da ACCase na cultura da soja. Planta Daninha 24:407-414.

Moreira, MS et al. 2010. Herbicidas alternativos para o controle de biótipos de Conyza bonariensis e C. canadensis resistentes ao herbicida glyphosate. Planta Daninha 28:167-175.

Nandula VK et al. 2006. Factors affecting germination of horseweed (Conyza canadensis). Weed Science 54:898-902.

Nowak KM et al. 2011. Formation and fate of bound residues from microbial biomass during 2,4-D degradation in soil. Environmental Science Technology 45:999-1006.

Oliveira Neto AM et al. 2010. Manejo de Conyza bonariensis com glyphosate + 2,4-D e amônio-glufosinate em função do estádio de desenvolvimento. Revista Brasileira de Herbicidas 9:73-80.

Oliveira Neto AM et al. 2017. Fall management of fleabane based on glyphosate+2,4-D, MSMA and glufosinate applied isolated or in tank mixture with residual herbicides. African Journal of Plant Science 11:151-159.

Plumb TR et al. 1977. Persistence of 2,4-D and 2,4,5 T in chaparral soil vegetation. Bulletin of Environmental Contamination and Toxicology 17:1-8.

Procópio SO et al. 2006. Eficácia de imazethapyr e chlorimuron em aplicações de pré-semeadura da cultura da soja. Planta Daninha. 24:467473.

Procópio SO et al. 2009. Utilização herbicida 2,4-D na dessecação de manejo em lavouras de soja no sistema de plantio direto. Magistra 21:187-193.

Rodrigues BN and Almeida FS. 2011. Guia de herbicidas. 6 ed. Londrina: Brazil.

Santos G et al. 2014. Multiple resistance of Conyza sumatrensis to chlorimuron-ethyl and to glyphosate. Planta Daninha 32:409-416.

Senseman SA. 2007. Herbicide handbook. 9 ed. Lawrence: Weed Science Society of America.

Steckel LE et al. 2006. Glyphosate-resistant horseweed (Conyza canadensis) control with glufosinate prior to planting no-till cotton (Gossypium hirsutum). Weed Technology 20:1047-1051.

Vangessel MJ et al. 2009. Influence of glyphosate-resistant horseweed (Conyza canadensis) growth stage on response to glyphosate applications. Weed Technology 23:49-53.

Vargas L et al. 2007. Buva (Conyza bonariensis) resistente ao glyphosate na região Sul do Brasil. Planta Daninha 25:573-578.

Vidal RA et al. 2007. Impacto da temperatura, irradiância e profundidade das sementes na emergência e germinação de Conyza bonariensis e Conyza canadensis resistentes ao glyphosate. Planta Daninha 25:309-315. 